\title{
Analysis of the importance of communicative and technical English language, in the Professional Schools of Mining Engineering of Peru for the innovation of extractive technologies of future professionals, 2019
}

\author{
Quispe Marcos, Parra Paola, Hinostroza Erika, Colque Daniel \\ Professional School of Mining Engineering, National University of Moquegua \\ Moquegua, Peru \\ mquispep@unam.edu.pe,pparrao@unam.edu.pe,erikacuatro20@gmail.com, \\ dcolquec17@gmail.com
}

\begin{abstract}
This project has as general objective to determine the relationship that exists between university students of the School of Mining Engineering and the proficiency of the communicative and technical English language, becoming familiar with innovations in extractive technologies during their academic preparation for their professional development in the labor field nationally and internationally 2019 .
\end{abstract}

Keywords. university accreditation, quality management, technical English in technological innovation.

\section{Introduction}

The objective of this research project was to determine the relationship that exists between university students of the School of Mining Engineering Schools and the proficiency of the communicative and technical English language, becoming familiar with innovations in extractive technology indexed in scientific journals, during their academic preparation for their professional development in the labor field at the national and international level 2019. It consists of five chapters.

Chapter I includes the theoretical framework that, in turn, is made up of the international and national antecedents of our research, as well as the theoretical bases of the variables (The importance of the English language and The Innovation of Extractive Technologies) and the definition of basic terms.

Chapter II, entitled Methodology, specifies the approach, method, design and type of research; the population, the sample, the sampling, as well as the techniques and instruments for data collection and statistical treatment.

Chapter III, entitled Results, includes the validity and reliability of the instruments, the presentation and analysis of the results in terms of descriptive and inferential levels, and the discussion of results.

Finally, the conclusions, recommendations, consulted references and appendices are included. 


\section{Chapter I: Theoretical Framework}

\subsection{National and International Background}

Today SINEACE (the National System of Evaluation, Accreditation and Certification of Educational Quality) evaluates the accreditation of Professional Engineering Schools in relation to technological innovation and environmental protection. And the scientific articles published in Scopus, SciELO, ESCI, are published in "Papers" of the English language, and the traditional teaching that was more conceptual due to objectives, nowadays the student is evaluated by competences, and one of them is KNOWING TO DO, more explicitly the PROCEDURAL competence, the student is the one who builds his/her learning through research, and explores innovative knowledge.

Jorge Berrocal Pérez-Albela, director of Studies of the Faculty of Sciences and Engineering of the Pontificia Universidad Católica del Perú (PUCP) (Pontifical Catholic University of Peru), explains that mastering English also helps to have greater access to information.

The professional school of Mining Engineering of the National University of Moquegua, has achieved awards in software operation in PERUMIN in recent years, qualifying to represent Peru in the 91st Annual Conference of the Society for Mining, Metallurgical and Exploration (SME) in the city of Minneapolis, Minnesota state in the United States.

According to Fiol Cuenca, Aguilera Saborít, Olive Herrera, Verdecia Cruz, \& Salgado Rodríguez (2010) in their research Curricular Strategy for English Language Learning in the Training of the Mining Engineer at the Higher Institute of Mining and Metallurgy, Moa, the results of the subject at the end of the English for Professional Purposes class and the strategy evaluation exam in the 4th year of the university career, better results are observed in the quality index from the application of the strategy in the 2005 - 2006 - 2007 academic year. As well as, the permanence of the students in the elective course of English Language in 4th year, before and after the implementation of the Strategy, observing an increase in permanence from the 2005-2006 academic year, when the strategy begins to be applied.

\subsection{Theoretical bases}

1.1.1. Technical English. Technical English does not have a formal definition since, unlike conventional English, it is based on a vocabulary focused on specific terms that will be applied in subjects and contexts typical of the area; that is, words that are not very common but are typical of the area are used. In the case of this research, it is technical English for the profession of Mining Engineering. Technical English is also known as Simplified English (SE) and it is defined as a subset of mainstream English, designed for specific purposes. In 1971, McDonnell Douglas, the American company dedicated to the manufacture of airplanes, published the first dictionary of technical English for aeronautics with terms approved for its field. Then, in 1986, the European Association for Aeronautical Material produced the first official and mandatory document on the use of technical English for all civil aviation projects. (Gisele Larriviere, 2018)

1.1.2. University Quality. Educational quality is a fundamental value of higher education, therefore, the choice of a definition of the strategy for ensuring it is important, according to the virtual encyclopedia. (Wildher Aguirre, 2017)

In the University Law No. 30220, the curriculum must be updated every three (3) years or when appropriate, according to scientific and technological advances.

Teaching a foreign language, preferably English, or teaching a native language, preferably Quechua or Aymara, is mandatory in undergraduate studies.

1.1.3. Professional Performance. Sandra Medina (2017), defines performance evaluation as a procedure that assesses the most orderly and objective aspect possible, the productivity of the employees in the institution. It will be carried out on the basis of the work developed, the responsibilities assumed, the objectives set and personal characteristics. 
1.1.4. University Accreditation. It is the formal recognition of the quality demonstrated by an institution or educational program, or educational program granted by the Peruvian State through the corresponding operating body, according to the external evaluation report issued by a duly authorized evaluation entity, in accordance with current regulations. Accreditation is temporary and its renewal necessarily implies a new process of self-evaluation and external evaluation. (María García, 2004)

The Accreditation Model for University Higher Education Study Programs - SINEACE, in dimension 2, of standard 22, explains that study programs manage, regulate and ensure the quality of $\mathrm{R}$ \& D \& I carried out by teachers, related to disciplinary area to which it belongs, in coherence with the university's $\mathrm{R}+\mathrm{D}+\mathrm{i}$ policy and in order to have a comprehensive knowledge, one must know the lingua franca that allows us to communicate.

1.1.5. Communicative English. Today, the communicative approach to English in the process of teaching and learning a second language is as accepted as the constructivist educational model of knowledge in general education and that they are fundamental for learning a second language from a combination of constructivism and the communicative approach. In 1971 Hymes proposed the term communicative competence to represent the use of language in the social context, combining language, communication and culture (similar to what Halliday and Firth did in Great Britain). In 1989 Nunan describes in a broader way when he says that the communicative approach of English involves "the learners in the understanding, manipulation, production or interaction in L2 while their attention is concentrated primarily on the meaning rather than on the form" . That is, each person builds their reality and their knowledge (or skills in the case of learning a language) in a fundamentally internal and individual process in continuous interaction with their social and cultural environment. (Liliana López, 2018)

1.1.6. Extractive Technology. The technology of extraction of a deposit in the mines is based on proprietary solutions developed during the course of the production activity that combine technologically advanced basic aspects of mining production such as, for example, extraction and transport, as well as the maintenance of the stability in the galleries. (KGMH POLSKA MIEDZ, 2020)

\section{Chapter II: Methodology}

\subsection{Type and design research}

Descriptive - Explanatory: Because it sought to measure the study variable, to describe them in the desired terms (Hernández et al., 2006, p. 326).

It seeks to explain the causes that originated the situation, in other words, it is the interpretation of a reality or the explanation of why? and for what? of the object of study. Explanatory, because it seeks to establish the causes in different types of study, establishing conclusions and explanations to enrich or clarify the theories.

The type of research is descriptive - explanatory, cross - sectional (transactional). Cross-sectional: Because the data was collected in a single moment, in a single time.

\subsection{Population and sample}

- Population: All students and professionals of the School of Mining Engineering of Peru.

- Sample: The following study is aimed at students and professionals of the School of Mining Engineering of the following universities and mining companies 
Table 1. Involved universities and mining companies in Peru.

University / Mining Company

Location

Universidad Nacional de Moquegua (National University of Moquegua) - UNAM

Moquegua

Pontificia Universidad Católica del Perú (Pontifical Catholic University of Peru) PUCP

Lima

Universidad Nacional de Ingeniería (National University of Engineering) - UNI

Lima

Universidad Nacional Mayor de San Marcos (National Major San Marcos

University) - UNMSM

Lima

Universidad Peruana de Ciencias Aplicadas (Peruvian University of Applied

Sciences) - UPC

Lima

Universidad Nacional de San Agustín (National University of San Agustín de Arequipa) - UNSA

Universidad Nacional de San Antonio Abad (National University of Saint Anthony the Abbot in Cuzco) - UNSAAC

Universidad Nacional Jorge Basadre Grohmann (Jorge Basadre Grohmann National University) - UNJBG

Tacna

Universidad Nacional del Altiplano de Puno (National University of the Altiplano) UNAP

Puno

Anglo American - Quellaveco

Southern Peru Copper Corporation - Cuajone

Moquegua

Compañía Minera Condestable S.A.

Lima

Sociedad Minera Cerro Verde

Arequipa

Southern Peru Copper Corporation - Toquepala

Tacna

Minsur S.A. - Unidad Minera San Rafael

Puno

The sampling was non-probabilistic for convenience. In this regard, Hernández et al. (2010) tell us that they are "simply available cases to which we have access" (p. 401).

The survey was used to measure the technical and communicative English variable. In this regard, Mejía (2005) affirms that this type of technique occurs through the construction of questions that the researcher formulates with respect to its variables and dimensions. This collects attitudes, interests, perceptions, among other personal behaviors. 


\section{Chapter III: Results}

\subsection{Presentation and analysis of the results.}

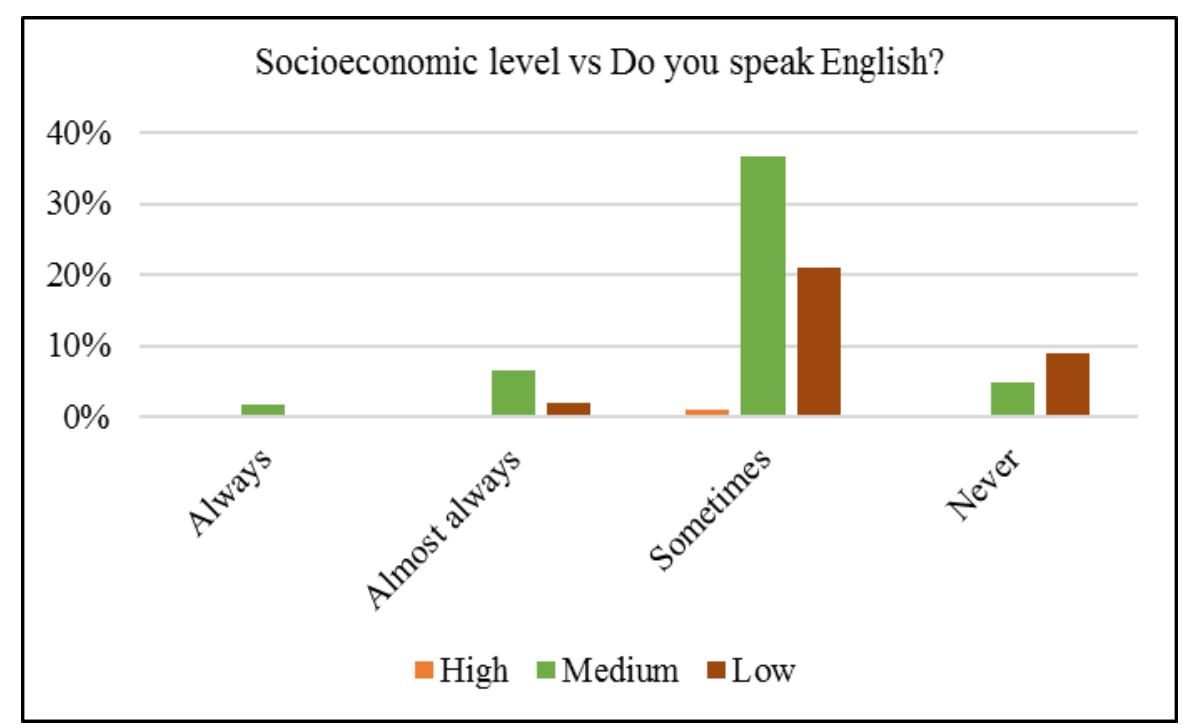

Fig. 1 Socioeconomic level vs Do you speak English? It is observed that students with a medium socioeconomic level speak English sometimes with 36.6\%. In contrast, students with a low socioeconomic level, with $9.0 \%$, never speak English.

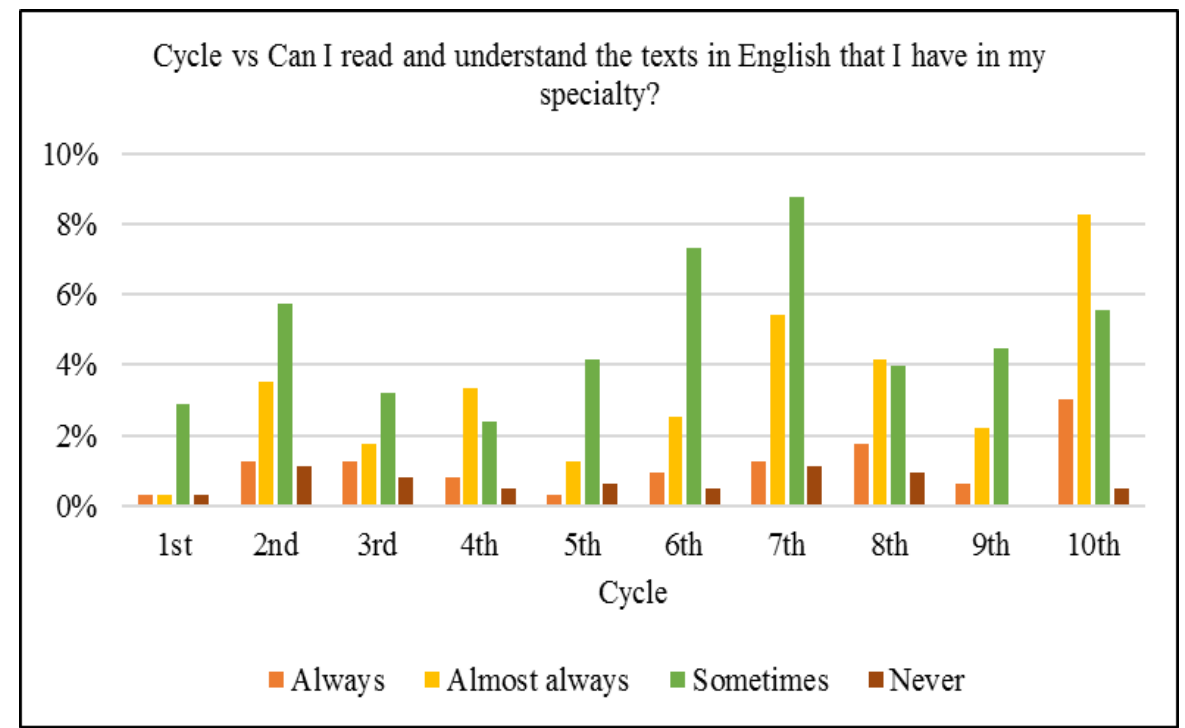

Fig. 2 Cycle vs Can I read and understand the texts in English that I have in my specialty? It is observed that the surveyed seventh cycle students with $8.8 \%$ indicate that they can sometimes read and understand these texts in English. 


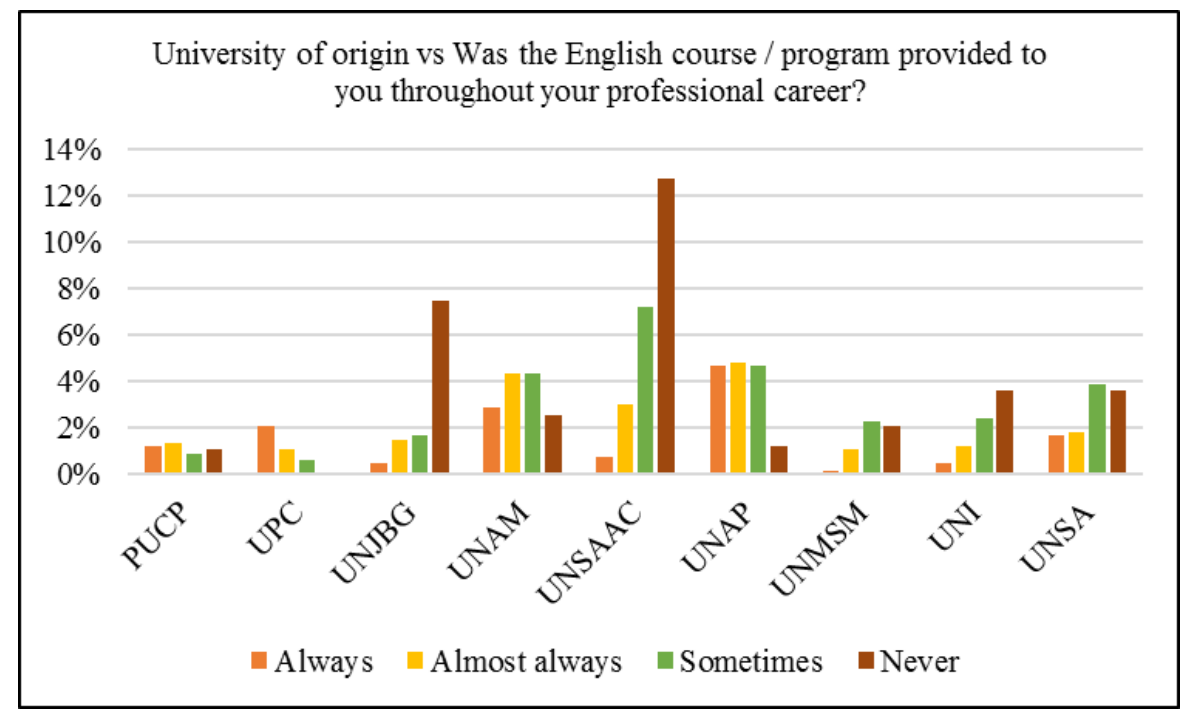

Fig. 3 University of origin vs Was the English course / program provided to you throughout your professional career? It is observed that UNSAAC students with $12.8 \%$ indicate that they were never provided an English program during their entire professional career. And with 4.7\%, UNAP students indicate that they were always provided with an English program in their professional career.

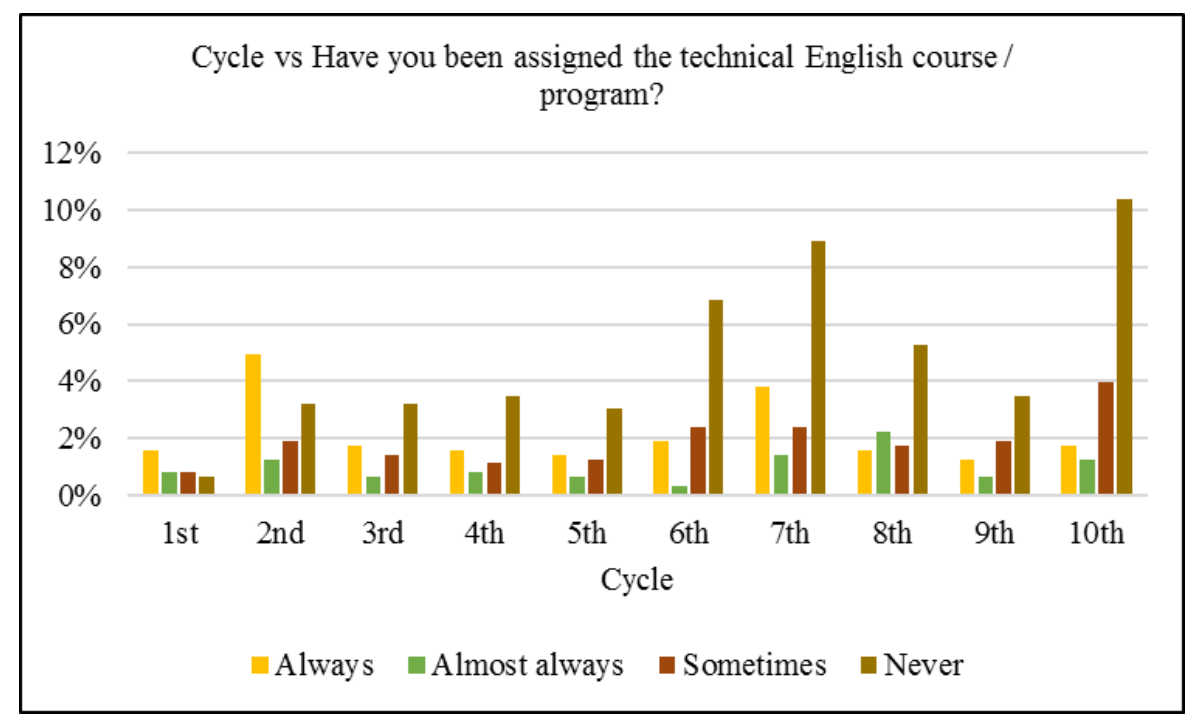

Fig. 4 Cycle vs. Have you been assigned the technical English course / program? It is observed that $10.4 \%$ of tenth cycle students indicate that their universities have never assigned them a course or program of technical English.

\section{Conclusions}

The present research determined that students from the different universities surveyed who are between 20 and 23 years old speak English sometimes. Which indicates that they would be in the final stage of their university careers, studying or speaking the English language due to the need to learn a foreign language to obtain an academic degree.

In addition, it is observed that students from universities in the capital have better opportunities to learn a foreign language, both in their institutions and in a private way, on the other hand, some students 
from provincial universities indicate that they were never provided with an English program throughout their professional careers, however, their teachers do motivate them to learn the English language.

It is observed that $37 \%$ of students with a medium socioeconomic level speak English sometimes. In contrast, students with a low socioeconomic level never speak English.

It is observed that approximately $60 \%$ of all students have a solid knowledge of the English language at the basic level; approximately $40 \%$ of all students have a solid intermediate level English language proficiency and approximately $25 \%$ of all students have a strong advanced level English language proficiency.

It is observed that approximately $60 \%$ of all students have basic technical knowledge about mining and extractive technologies.

Finally, it is observed that approximately $75 \%$ of the total professionals surveyed from different companies consider English to be an essential requirement to choose a managerial and directive position, and to choose an international job.

\section{Recommendations}

After completing this research, and after having discovered how interesting learning the English language is and its importance in the professional development of Mining Engineering students. It has been proven that there are great opportunities to learn a foreign language in the capital of our country, and the great deficiencies that low-income students and provincial universities have to deal with. However, it is important to emphasize that students are aware of the need and importance of learning the English language for their professional and personal development.

Here are some recommendations from this research:

- It is important that public and private universities include technical English courses in their curricular plans, and reinforce teaching in language centers so that first-cycle students have a good foundation in the management of the English language.

- It would be interesting to promote English scholarships to outstanding low-income students so that they do not see their professional performance truncated at the end of their degree, so that they are sufficient motivation for future students to understand the need to master a foreign language and the opportunities that this provides for them.

- Provide necessary training to university professors, so that they motivate their students and help them understand that we are in a globalized world, and this requires that we integrate through mastery of the English language.

- It is essential to promote research with references in English, as a means of using this language, in addition to the fact that the most up-to-date information on any subject, especially in mining and extractive technologies, is in this language.

Finally, we hope that, from the data obtained and the conclusions shown, this research will be useful and of interest to university students and teachers of the Mining Engineering career.

\section{Acknowledgment}

To all the deans and directors of the Schools of Mining Engineering of Peru for opening the doors of their Universities to apply our Evaluation Instruments. To the administration of the National University of Moquegua, represented by Dr. Alberto Quispe Cohaila, Vice President of Research, for allowing us to carry out the research on behalf of our University. A special thanks to our collaborators: Yosemar Diego Noa Jorge, Jhonatan Ricardo Hinostroza Vidal, Donny Alexander Alcázar Alvarez, Primo Nash Chaiña Corimanya, Frank Lloyd De La Cruz Carrasco and Roberto Carlos Melendrez Flores; students from the last semesters of EPIM-UNAM (Professional School of Mining Engineering - National University of Moquegua). 


\section{References}

[1] W. Aguirre, Evaluación de la Calidad de Servicio Universitario desde la percepción de estudiantes y docentes en la Universidad Privada de la Selva Peruana. Perú: Universidad Privada de la Selva Peruana, $2017 . \quad$ Recuperado de: http://repositorio.ups.edu.pe/bitstream/handle/UPS/28 /TESIS\%20Aguirre-EspinozaWildher.pdf? sequence $=4 \&$ isAllowed $=y$

[2] S. Medina, Desempeño laboral del personal administrativo nombrado de la Municipalidad Provincial del Santa. Perú: Universidad César Vallejo, 2017. Recuperado de: http://repositorio.ucv.edu.pe/bitstream/handle $/ 20.500 .12692 / 12001 /$ medina_cs.pdf?sequence $=1$

[3] G. Larriviere, El aprendizaje del inglés técnico y la formación de periodistas del cuarto ciclo de la Universidad Jaime Bausate y Meza. Perú: Universidad Católica Sedes Sapientae, 2018. Recuperado de: http://repositorio.ucss.edu.pe/bitstream/handle/UCSS/588/Larriviere Gisele tesis maestria 2018.pdf? sequence $=1$ \&isAllowed $=y$

[4] M. García, La acreditación de las instituciones de educación superior en América Latina. Perú: Pontificia Universidad Javeriana, 2004. Recuperado de: https://www.javeriana.edu.co/biblos/tesis/derecho/dere6 /DEFINITIVA/TESIS53.pdf

[5] L. López, El enfoque comunicativo y aprendizaje del idioma ingles en los estudiantes del Centro de idiomas de la Universidad Nacional "Daniel Alcides Carrión". Perú: Universidad Nacional Daniel Alcides Carrión, 2018. Recuperada de: http://repositorio.undac.edu.pe/bitstream/undac /1020/1/T026_04072304_M.pdf

[6] KGMH POLSKA- MIEDZ, Tecnología de extracción de mineral, 2020. Recuperado de: https://kghm.com/es/negocio/procesos/tecnologia-de-extraccion-de-mineral.

[7] Fiol Cuenca, Aguilera Saborít, Olive Herrera, Verdecia Cruz, \& Salgado Rodríguez (2010) en su investigación Estrategia Curricular para el Aprendizaje de Idioma Inglés en la Formación del Ingeniero en Minas en el Instituto Superior Minero Metalúrgico de Moa. Recuperado de: file://C:/Users/PAOLA/Downloads/441-898-3-PB.pdf

[8] Gisele Larriviere (2018), el primer documento oficial y mandatorio sobre el uso de inglés técnico para todos los proyectos de aviación civil. Recuperado de: https://www.icao.int/Meetings/lpr13/Documents/323_es.pdf

[9] Ley Universitaria $\mathrm{N}^{\circ} 30220$, promulgado el 9 de julio de 2014 y publicado en la página oficial del diario oficial El Peruano, objeto normar la creación, funcionamiento, supervisión y cierre

[10] de las universidades. Promueve el mejoramiento continuo de la calidad educativa de las instituciones universitarias como entes fundamentales del desarrollo nacional, de la investigación y de la cultura. Recuperado de: http://drec.minedu.gob.pe/reformauniversitaria/pdf/ley_universitaria.pdf

[11] El Modelo de Acreditación para Programas de Estudios de Educación Superior Universitaria SINEACE, en la dimensión 2, del estándar 22, aprobado en octubre ,2016. Recuperado de: https://www.sineace.gob.pe/wp-content/uploads/2014/08/Anexo-1-nuevo-modeloprogramas-Resolucion-175.pdf

[12] Hymes (1971) competencia comunicativa para representar el uso del idioma en el contexto social, combinando el idioma, la comunicación y la cultura Recuperado de: https://scielo.conicyt.cl/scielo.php?script=sci_arttext\&pid=S0071-17132001003600010 .

[13] Hernández et al., 2006, p. 326 Metodología de la investigación científica

[14] https://www.esup.edu.pe/descargas/dep_investigacion/Metodologia\%20de $\% 201 \mathrm{a} \% 20$ investigaci $\%$ C3\%B3n\%205ta\%20Edici\%C3\%B3n.pdf 